\title{
Improving the manufacturability of floor slabs by pre-installing elements that partially replace reinforced concrete and formwork
}

\author{
Seyran Akimov*, Olga Balakchina, Elvira Akimova, Vladimir Malahov and Vasilij \\ Shalenny \\ Crimean Vernadsky Federal University, 295493, Simferopol, Republic of Crimea, Russia
}

\begin{abstract}
The article discusses well-known and perspective constructive and technological systems for the installation of monolithic and precastmonolithic floor slabs of civil and industrial buildings. It shows examples and expediency of using all kinds of inserts made of plastic and other light materials and products for replacing a part of heavy monolithic reinforced concrete. An original resource-saving method for the installation of precast-monolithic floor slabs with a simultaneous increase in the degree of their construction readiness is proposed. This effect is achieved by reducing their own weight and the use of permanent formwork. Reduction in own weight of the precast-monolithic floor slab is ensured by the use of volumetric lightweight trapezoidal or rectangular inserts, preferably made of expanded polystyrene, during its installation. The use of permanent formwork will eliminate the need for the subsequent performance of laborintensive finishing and insulation works. To confirm the effectiveness of using the proposed method of precast-monolithic floor slab installation, the operation of two floor slabs was modeled in the LIRA SAPR computing complex - the proposed reinforced concrete innovative slab and a solid reinforced concrete slab. Having analyzed the calculated forces, deformations and the corresponding consumption of reinforcement and concrete, comparative indicators were obtained for the proposed innovative slab and for a typical solid floor slab. As a result, significant savings in material and cost have been proven.
\end{abstract}

\section{Introduction}

In modern monolithic construction, the priority task is to reduce the material consumption of the structure by applying technological methods for the rational use of materials, as well as reducing labor costs for the entire construction period. The installation of monolithic reinforced concrete floor slabs is an important and necessary stage in the construction life cycle. The disadvantage of such an floor slab is the high own weight of the structure. Because of this, it is required to strengthen all the supporting elements of the building frame. This need leads to an increase in the consumption of materials, labor costs, and, as a result, an increase in financial costs for construction. Based on this, effective constructive

*Corresponding author: seyran-23@mail.ru 
and technological solutions for lightweight precast-monolithic floor slabs have been developed recently.

For example, the use of lightweight expanded polystyrene inserts in the thickness of reinforced concrete floor slabs leads to a decrease in their own weight and, as a result, to a decrease in loads on floor slabs, vertical structures and foundations, which makes it possible to reduce the material consumption of these structural elements. And the use of permanent formwork allows you to reduce labor costs for assembly and disassembly of the formwork. Thus, due to the use of permanent formwork and expanded polystyrene inserts, the installed structure will immediately have an increased degree of construction readiness, which, in its turn, will lead to savings in labor costs and other resources. The aforementioned determines the relevance of further scientific research and pre-design developments aimed at saving resources in the installation of floor slabs by applying innovative solutions in their constructive and technological directions.

To replace prefabricated housing construction, in the last two to three decades, monolithic reinforced concrete frame structural systems have become most widespread due to their increased rigidity and ease of production of reinforced concrete work in collapsible industrial formwork systems directly at the construction site [1]. At the same time, such technologies also have a number of significant disadvantages associated, first of all, with their increased labor intensity and long terms of work completion. Therefore, both in the post-Soviet countries and in the far abroad, compromise precast-monolithic constructivetechnological systems of low-rise civil construction are becoming more widespread [2]. In our further work, we will show the possible directions of intensification and the results of improving the technical and economic indicators of the installation of precast-monolithic reinforced concrete floor slabs through their research and resource-saving improvement.

After all, the share of prefabricated monolithic structures for floor slabs in the EU countries, according to various estimates, ranges from $20 \%$ to $35 \%$ [3]. In Russia, such floor slabs were not used at all until 2008. While such structures have a lower own weight, higher heat and sound insulation performance, they do not require the use of powerful lifting equipment and other associated labor costs [4]. Focusing on well-known foreign precast-monolithic systems, such as (Fig. 1): Porotherm floor slab (Austria, hollow inserts made of ceramic blocks); TERIVA floor slab (Poland, hollow concrete inserts, including expanded clay concrete); YTONG floor slab (Sweden, aerated concrete blocks); Rectolight floor slab (France, curved pressed wood inserts); FIT SLAB floor slab (Italy, stamped plastic ribbed liners), the Russian Federation patented and is developing a domestic innovative technology SMP MARCO [5-7].
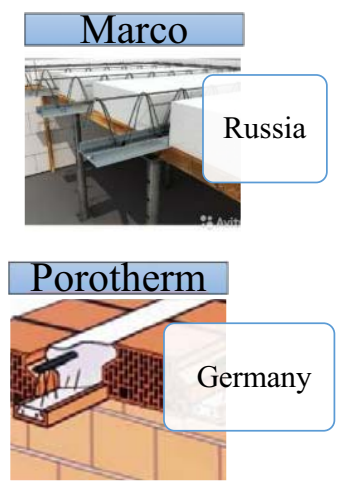
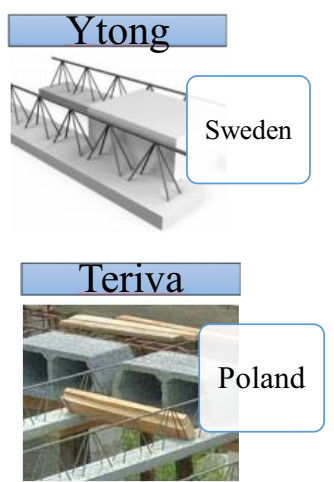

\section{Rectoligt}

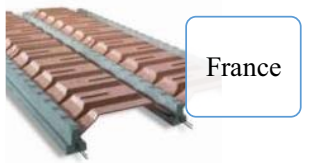

\section{IZH 670}

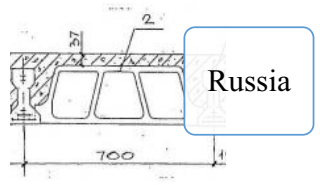

Fig. 1. Common systems of precast-monolithic floor slabs with block inserts made of stone materials

A similar system with filling made of polystyrene concrete blocks BETOBLOK also becomes popular. Only the absence of nearly located factories specializing in the 
manufacture of precast elements of this system hinders the widespread use thereof. In addition, revision and a comparative assessment of the cost of similar structures, but with different filling materials, are required. Our suggestions on the use of inserts made of limestone (shell rock) blocks as a local material for the construction of low-rise buildings (Fig. 2), [8] can also be considered one of its possible improvements.

Modification thereof is in replacing the pre-fabricated precast reinforcing-formwork block with two elements that allow their manufacture under construction conditions - a spatial reinforcement cage and a formwork base board, on which the mentioned reinforcement cage was mounted with a gap that provides the required thickness of the concrete cover.

Another possible and practical way of reducing own weight of flat floor slabs in a precast-monolithic building frame is also the replacement of a part of concrete with plastic inserts of various shapes: balls and similar bodies of revolution (Bubble Deck technology), rectangular parallelepipeds (NAUTILUS technology), etc. In their projects, the developers show up to $35 \%$, and even up to $50 \%$ savings in reinforced concrete with the resulting other improved technical and economic indicators (cost, timing) [9, 10]. Analytical studies of comparative strength and deformation properties of such systems in comparison with a solid reinforced concrete slab were also carried out [11]. However, such studies in the aforementioned work have not been brought to the level of assessing the economic efficiency of technology implementation at specific sites.
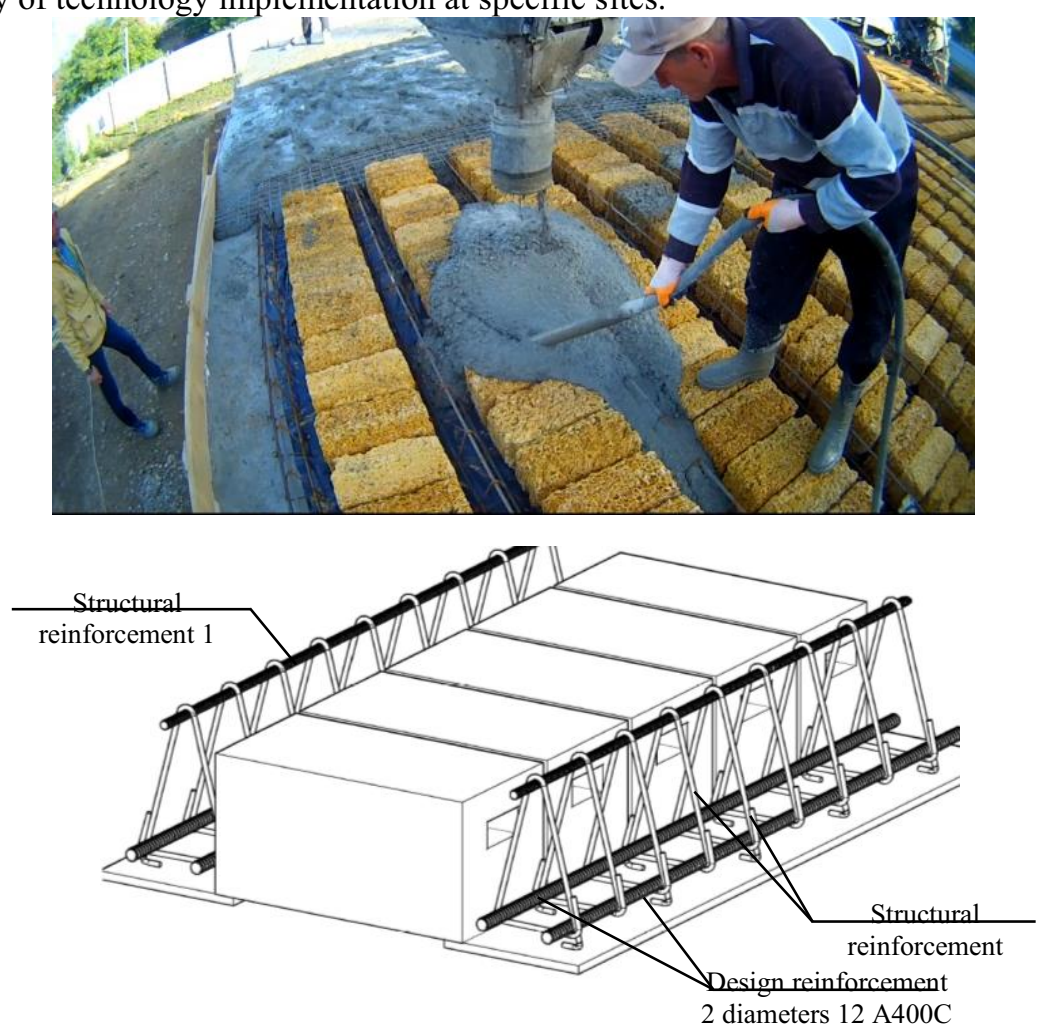

Fig. 2. The concreting process and the basic structural diagram of the inserted floor slab with inserts made of shell rock or polystyrene concrete blocks

Well-known Russian experts also paid attention to the listed structural systems, and proposed to use them to replace wooden floor slabs, as the most material-intensive structures of civil buildings, in particular, during their overhaul [12]. The authors have 
developed and recommended technologies for the reconstruction of floor slabs using nonremovable spherical and prismatic inserts made of plastic and expanded polystyrene, providing a reduction in the duration of works by $18-20 \%$ with a corresponding improvement in other economic and operational indicators. The possibility of using lightweight structures when replacing floor slabs in reconstructed buildings is considered in the article [13]. It is noted that this allows to reduce the load on the existing structures of walls and foundations, as well as to reduce the material consumption of the floor slabs themselves.

The possibility of using hollow forms in the installation of monolithic foundations is also considered. This is how the foundation slab of the middle part of the stylobate of a residential complex in the Moscow region was designed, where the calculation of the base plate was carried out in the SCAD Office software package (version 21.1). Saving of concrete was $22.3 \%$, reinforcement - 5\% [14].

Specialists of the Pridneprovsk State Academy of Civil Engineering and Architecture under the leadership of Professor N.V. Savitsky predict a reduction in capital costs in general by up to $40 \%$ when using square-section void-formers made of expanded polystyrene of rationally selected shape and size $[15,16]$. But this requires not only a constructive, but also a technical and economic assessment of the inevitable complication of the works arrangement.

After conducting a patent search, studying information from the Internet and a literary review, partially presented here, an original construction of a flat monolithic floor slab was synthesized and patented, which has distinctive features and a new technical result, which consists in reducing the consumption of reinforced concrete by taking into account the actual work of the section of such reinforced concrete structure [ 17]. The specified technical result is achieved by the fact that the construction of a monolithic floor slab, having an upper and lower wire mesh, located in horizontal planes, between which there are rows of frames alternating with inserts. The space between these inserts is filled with concrete, and the inserts themselves are made with detachable legs, consisting of at least two parts (Fig. 3). As can be seen in this figure, the inserts are spatial volumetric bodies of revolution, the shape of which is close to the shape of a pear.

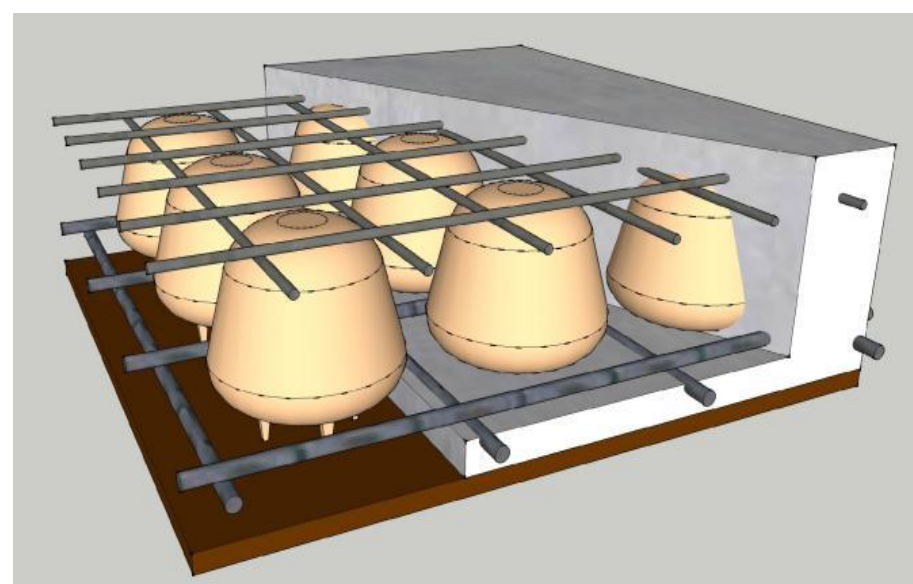

Fig. 3. Fragment of a floor slab structure with the replacement of a part of heavy concrete with plastic inserts 
We also consider perspective the structures of reinforced concrete interfloor floor slabs with permanent formwork with precast-monolithic bearing beams, between which all kinds of inserts are placed, replacing reinforced concrete with a lighter construction material, for example, expanded polystyrene, on top of which a thin reinforced concrete slab is then concreted. This leads to significant savings in heavy concrete, reduction of own weight of the floor slab, thereby reducing the calculated constant load from the floor slab, for which the supporting structures are designed and the costs of finishing and insulation work of the resulting ceiling surface are reduced. An example of such system is the use of permanent formwork made of fiberboard boards with expanded polystyrene inserts or fiberboard (arbolite) boards according to the VELOX technology (Fig. 4).

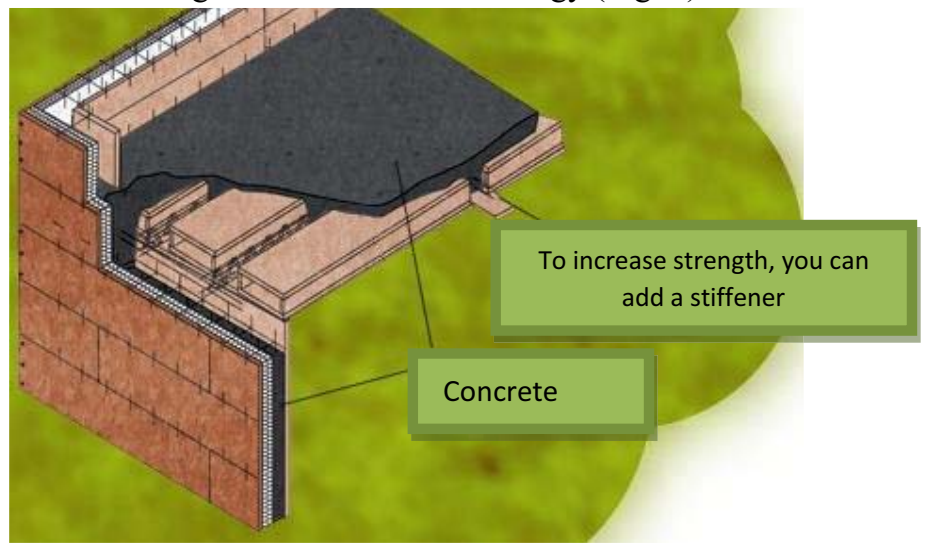

Fig. 4. VELOX - technology of low-rise civil construction

Developers and manufacturers call such slabs chip cement [18]. Similar slabs based on wood chips can also be produced using the carbonate hardening dolomite binder developed by our scientists [19]. In addition to saving material and labor costs during the production of the floor slab itself, you will get a ceiling surface that usually requires only finishing, which is certainly a more technological solution, since it does not provide for timeconsuming wet plaster or widespread cladding with gypsum plasterboard sheets. However, this structural and technological system usually provides for the support of the floor slabs only on the longitudinal bearing walls, i.e. is used mainly as a beam.

Its further resource-saving development, we believe, is also the use of a slab precastmonolithic floor structure, resting upon all four sides. In this version of the system, the combination of a monolithic reinforced concrete belt and a precast-monolithic floor slab according to the improved VELOX technology resting upon all sides will provide a more significant synergistic effect of saving materials, especially heavy reinforced concrete. To solve this problem, a precast-monolithic reinforced concrete floor slab is proposed, consisting of conjointly made slabs and beams with reinforcement, located in two directions and forming a mesh with a side ratio of less than two. In this case, the reinforcing cages of the beams have a triangular shape in a plane perpendicular to their longitudinal axes, and the reinforcing mesh of the slab is connected to the reinforcing cage of each beam, which has a triangular shape. Between the mentioned beams there are cells not filled with concrete, which are located in the space between the beams to the slab (Fig. 5), RF patent for utility model No. 190006 [20].

Using the proposed floor slab structure, even in the technological process of its manufacture, it will be possible to obtain a constructive system that ensures the performance of load-bearing, insulating and finishing functions without the need for the subsequent implementation of most time-consuming and heavy finishing and insulation works. This is ensured by a pre-fabricated hermetically sealed continuous permanent 
formwork. The proposed clamps simultaneously play the role of rigid connections of individual shields into a geometrically stable and unchangeable system [21]. Thus, the arranged structure of the precast-monolithic floor slab will have an increased degree of construction readiness immediately after its manufacture in one complex constructiontechnological process. Consequently, the proposed technology intensifies the complex construction process, reduces its labor intensity and cost.

It is possible to confirm the stated assumptions by means of experimental and theoretical studies of the comparative efficiency of the presented constructive and technological solutions for interfloor precast-monolithic floor slabs. To confirm the advanced hypothesis about the effectiveness of the presented scientific and design developments of precast-monolithic floor slab structures, it is necessary to simulate the operation of two floor slabs - the original solid reinforced concrete slab and an innovative slab with a permanent formwork and expanded polystyrene inserts. Computer modeling of the stress-strain state with the design of the structure and principal reinforcement must be carried out in the LIRA-SAPR computing complex; it is also necessary to perform calculations and assess the technical and economic indicators of the proposed technologies.

\section{Materials and Methods}

To assess the comparative effectiveness of the proposed structural and technological system of precast-monolithic floor slabs, the problem of computer modeling of the operation of the proposed innovative reinforced concrete precast-monolithic slab and a reinforced concrete solid slab at the same representative object was set and solved. The computational experiment was implemented at a specific object - a multi-storey building designed in the city of Sevastopol. The designed sectional-type residential building, 9-storey, with one entrance, frame with the outer walls filled with foam concrete blocks, with a technical underground and a flat unexploited roof. The building has a complex shape, close to a rectangular one in plan with dimensions in the axes of $37.2 \times 22.5 \mathrm{~m}$ (Fig. 6). The building is $38.72 \mathrm{~m}$ high.

The innovative floor slab is structurally a bearing ribbed system with mutually perpendicular ribs of the same height and a continuous thin horizontal slab on top. Such floor slab is formed using permanent formwork and expanded polystyrene inserts on it (Fig. $5)$.

The thickness of the shelf of the floor slab was determined subject to several conditions. The first of these was to ensure the required strength of the shelf itself with a minimum use of resources. Depending on the purpose of the building and premises, the nature of the loads that are transmitted to the floor slab changes.

The second prerequisite was the provision of normalized concrete cover thicknesses for the shelf reinforcement. On the other hand, the thickness of the shelf had to be reduced to make the structure as lightweight as possible. Based on this, one can come to the statement that the thickness of the shelf should be such that the reinforcement lies in one layer in two directions, i.e. it is reinforced with one mesh. 

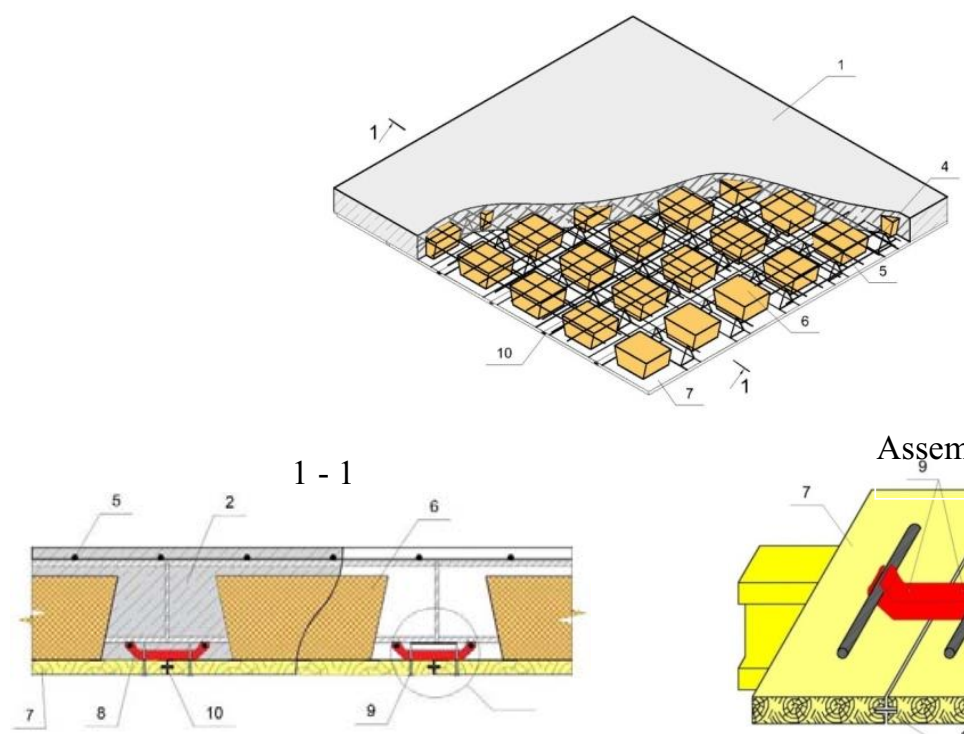

Assembly A

Asşembly A

Fig. 5. Improved precast-monolithic reinforced concrete floor slab according to the basic VELOX technology: 1 - precast-monolithic slab; 2 - monolithic beam; 3 - reinforcement; 4 - reinforcing cages; 5 - reinforcing mesh of the slab; 6 - trapezoidal expanded polystyrene inserts; 7 - permanent plank formwork; 8 - position clamps of the lower reinforcement; 9 - self-tapping screws; 10 - tongue-andgroove connection of wood concrete boards

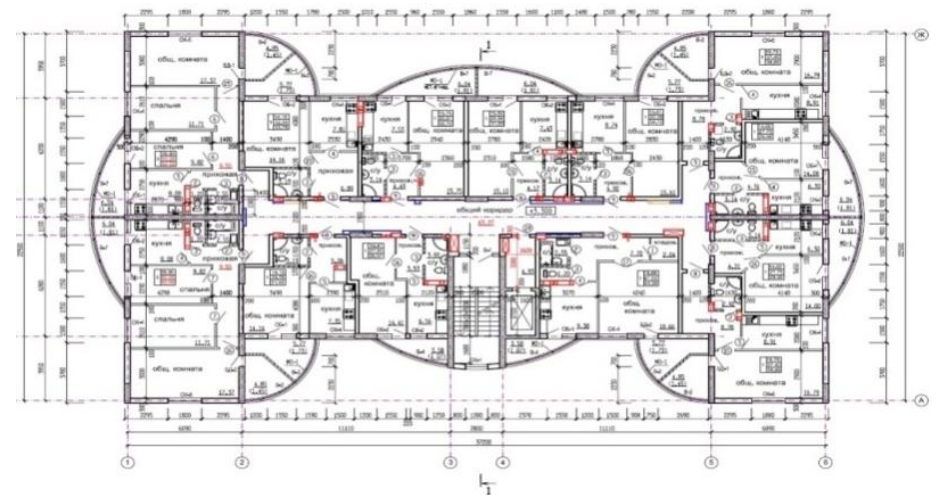

Fig. 6. Typical floor plan of the designed building

The floor slabs were calculated for the effect of calculated permanent, long-term and short-term loads, special loads, as well as combinations thereof. The spatial design of the floor slab is statically indeterminate. The calculation was carried out using a computational complex (PC LIRA-SAPR) using the finite element method. Further, permanent, temporary and short-term loads per $1 \mathrm{~m}^{2}$ of a solid floor slab were collected, and also the own weight of the slab was taken into account. The loads per $1 \mathrm{~m}^{2}$ of the innovative slab were assumed to be the same as for a solid base slab.

\section{Results}

The results of processing design schemes, displacement isofields, bending moments, required reinforcement for two slab options are summarized and presented in a tabular form 
(Table 1), and a summary of material consumption and the cost thereof are presented in Table. 2, fig. 7. Master Dogoshapko I.M. took part in the calculations.

Table 1. Comparative characteristics of computer models and the results of calculations for rational design of the considered options for interfloor structures

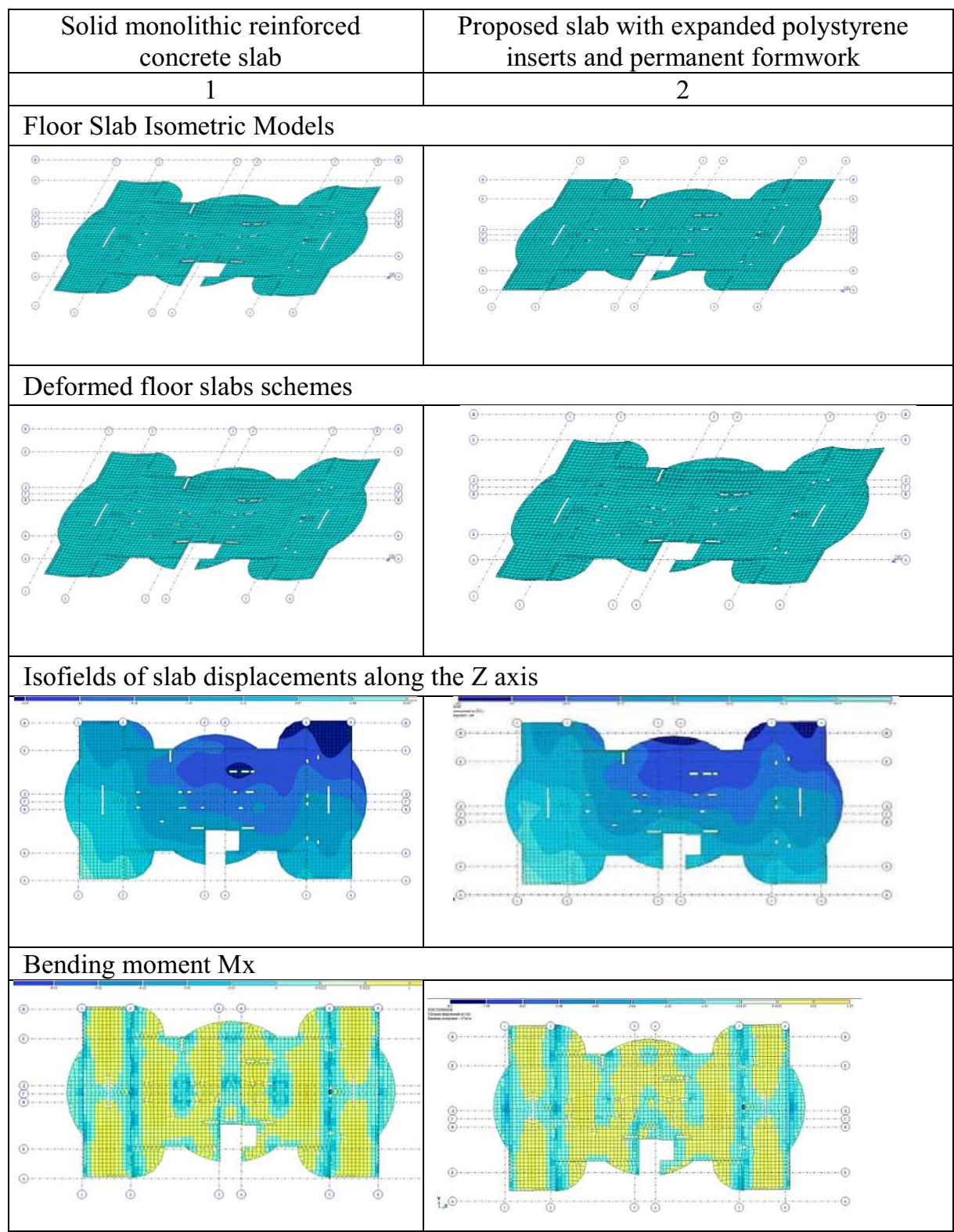

Table 1 (continued)

Bending moment My 


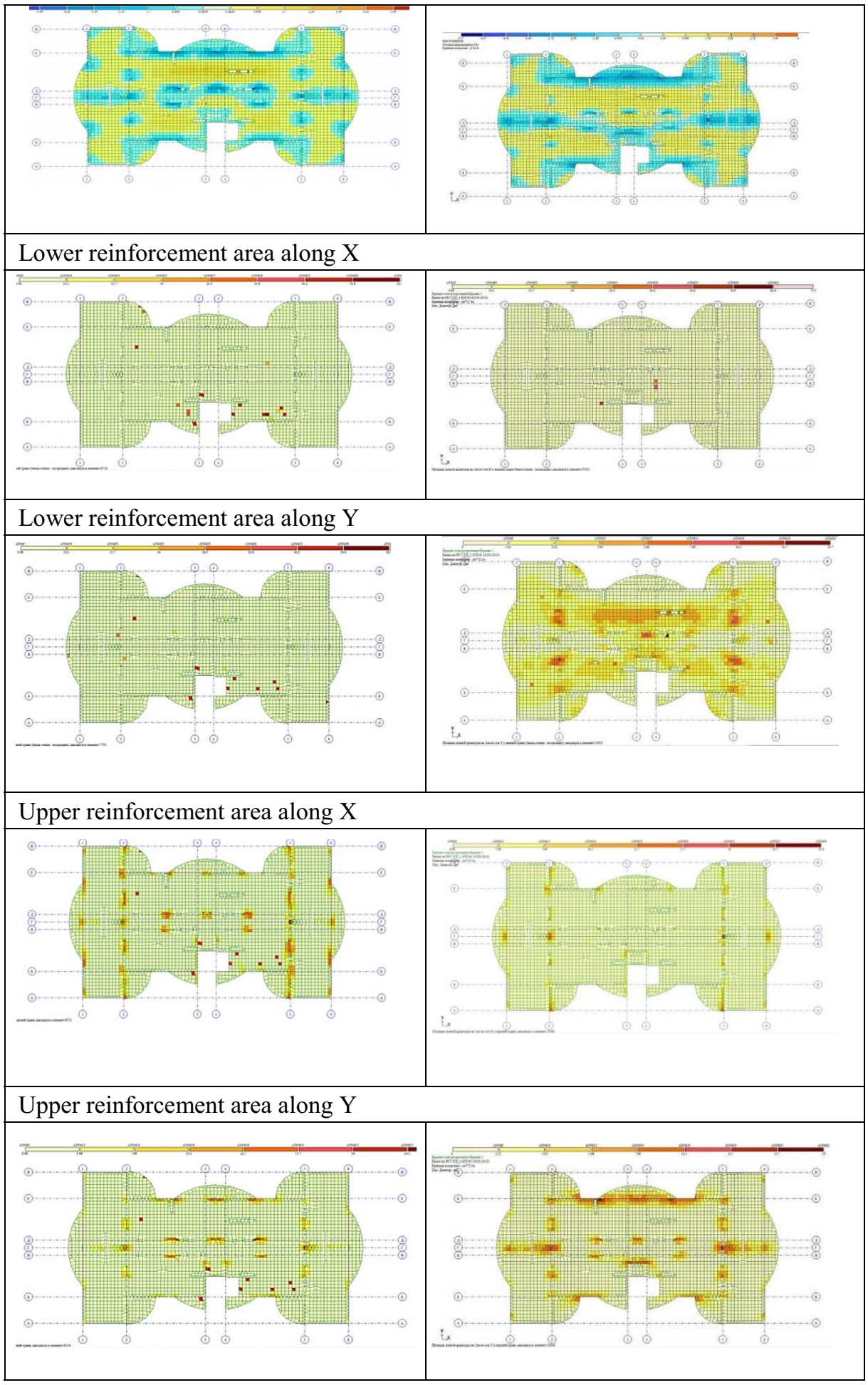

Table 2. Comparison of material consumption based on the results of modeling the operation of the 
considered competing floor structures

\begin{tabular}{|c|c|c|c|c|c|c|c|}
\hline \multicolumn{3}{|c|}{ Reinforcement A500 } & \multirow{2}{*}{$\begin{array}{l}\text { Cost, } \\
\text { thousand } \\
\text { Rub. }\end{array}$} & \multirow{2}{*}{$\begin{array}{l}\text { Concrete } \\
\text { B25, } \\
\mathrm{m}^{3}\end{array}$} & \multirow{2}{*}{$\begin{array}{l}\text { Expanded } \\
\text { polystyrene, } \\
\text { thousand Rub. }\end{array}$} & \multirow{2}{*}{$\begin{array}{l}\text { Permanent } \\
\text { formwork, } \\
\text { thousand } \\
\text { rubles }\end{array}$} & \multirow{2}{*}{$\begin{array}{l}\text { Cost, } \\
\text { thousand } \\
\text { Rub. }\end{array}$} \\
\hline & Diameter & Tons & & & & & \\
\hline 1 & 2 & 3 & 4 & 5 & 6 & 7 & 8 \\
\hline \multicolumn{8}{|l|}{ Solid slab } \\
\hline $\begin{array}{l}\text { Lower } \\
\text { reinfor- } \\
\text { cement }\end{array}$ & $\begin{array}{l}\varnothing-10 \\
\varnothing-12\end{array}$ & $\begin{array}{l}0.73 \\
13.83\end{array}$ & $\begin{array}{l}30295 \\
549051\end{array}$ & \multirow{3}{*}{169} & \multirow{3}{*}{ - } & \multirow{3}{*}{-} & \multirow{3}{*}{845000} \\
\hline $\begin{array}{l}\text { Upper } \\
\text { reinfor- } \\
\text { cement }\end{array}$ & $\begin{array}{l}\varnothing-10 \\
\varnothing-12 \\
\varnothing-16 \\
\end{array}$ & $\begin{array}{l}0.05 \\
0.97 \\
2.27 \\
\end{array}$ & $\begin{array}{l}2075 \\
38509 \\
88984 \\
\end{array}$ & & & & \\
\hline $\begin{array}{l}\text { Strengthe- } \\
\text { ning }\end{array}$ & $\varnothing-18$ & 1.06 & 41552 & & & & \\
\hline Total & - & 18.91 & 750466 & 169 & - & - & 845.000 \\
\hline $\begin{array}{l}\begin{array}{l}\text { Total floor } \\
\text { slab }\end{array} \\
\end{array}$ & - & - & - & - & - & - & 1595466 \\
\hline \multicolumn{8}{|l|}{ Innovative slab } \\
\hline Upper mesh & $\varnothing-8$ & 3.19 & 131855 & \multirow{3}{*}{89.7} & \multirow{3}{*}{36180} & \multirow{3}{*}{$\begin{array}{l}28525 \\
8\end{array}$} & \multirow{3}{*}{448500} \\
\hline $\begin{array}{l}\text { Reinforce- } \\
\text { ment of } \\
\text { frameworks }\end{array}$ & $\begin{array}{l}\varnothing-6 \\
\varnothing-10 \\
\varnothing-12\end{array}$ & $\begin{array}{l}0.43 \\
0.74 \\
4.26 \\
\end{array}$ & $\begin{array}{l}19384 \\
38515 \\
207053\end{array}$ & & & & \\
\hline Strengthening & $\varnothing-18$ & 1.06 & 41552 & & & & \\
\hline Total & - & 9.68 & 438.359 & 89.7 & 36180 & $\begin{array}{l}28525 \\
8 \\
\end{array}$ & 448500 \\
\hline $\begin{array}{l}\text { Total floor } \\
\text { slab }\end{array}$ & - & - & - & - & - & - & 1208297 \\
\hline
\end{tabular}

\section{Concrete consumption, $\mathrm{m} 3$}

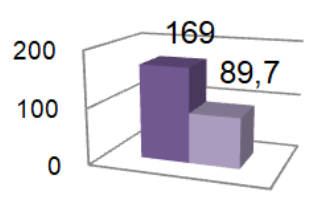

- Solid slab

- Innovative slab

\section{Reinforcement consumption, $t$}

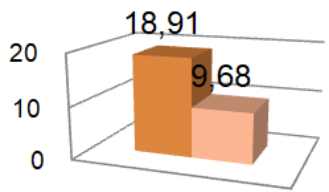

- Solid slab

- Innovative slab

Total cost, ub

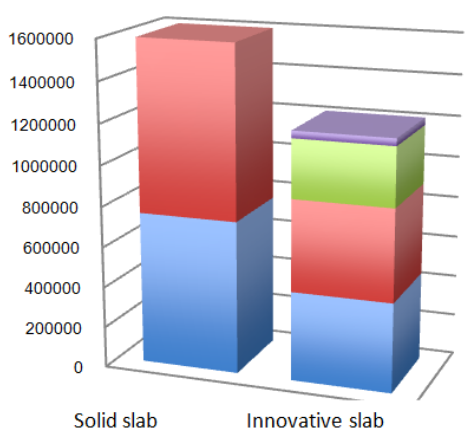

- Permanent formwork

- Expanded polystyrene

- Concrete

- Reinforcement

Fig. 7. Material consumption histograms

\section{Discussion}

As can be seen from the presented results, the proposed innovative design of precastmonolithic floor slab provides significant savings in material resources: steel - by $26 \%$ and 
concrete mix by $47 \%$. The results obtained do not go beyond the limits noted by other researchers and designers $[9,10]$. In value terms, the savings on materials are 387 thousand rubles per floor slab. Consequently, the proposed design will be more technologically advanced in production compared to the traditional solid floor slab. Additionally, the cost items not taken into account when modeling the economic effect are to reduce the labor intensity and cost of subsequent finishing work. Reduction of own weight of the structure of the interfloor floor slabs entails a decrease in other material costs - for the installation of foundations and load-bearing elements of the frame. In addition, a reduction of own weight of this frame has a positive effect on a decrease in inertial seismic loads, which is important for earthquake-resistant construction in Crimea.

\section{Summary}

This is a scientifically substantiated and patented Russian technology for the installation of precast-monolithic reinforced concrete floor slabs with expanded polystyrene inserts in a permanent formwork. By modeling two competing design solutions in the LIRA-SAPR computing complex - monolithic and precast-monolithic floor slabs, we demonstrate a significant saving in materials when using an innovative solution: concrete - almost $47 \%$, metal $-26 \%$, which in value terms is $24.6 \%$. Consequently, the developed technology of the floor slab installation can be recommended as a resource-saving one for further study and use in construction practice.

\section{References}

1. V.T. Shalenny, O. Kapshuk, Manufacturability of demountable and movable formwork systems (Saazbrucken, Germany, Lap LAMBERT Academic Publishing GmbH \& Co. KG, 2015).

2. V.T. Shalenny, O. L. Balakchina, Precast-monolithic housing construction: textbook (IPR Media, Saratov, 2018).

3. Zh.S. Teplova, N.A. Vinogradova, Precast-monolithic floor slabs of the "MARKO" system Construction of unique buildings and structures 8 (35) 48-59 (2015).

4. G. D. Shmelev, N. A. Fomenko, V. N. Gavrilova, Comparative analysis of modern systems for the construction of civil buildings Housing and communal infrastructure 3 (6) 9-19 (2018).

5. E.S. Nedviga, N.A. Vinogradova, Systems of precast-monolithic floor slabs Construction of unique buildings and structures 4 (43) 87-102 (2016).

6. N.I. Vatin, V.Z. Velichkin, G.L. Kozinets, V.I. Korsun, V.A. Rybakov, O.V. Zhuvak, Technology of precast-monolithic reinforced concrete beam floor slabs with expanded clay concrete blocks Construction of unique buildings and structures 7 (70) 43-59 (2018). DOI: 10.18720/CUBS.70.4.

7. V.A. Bryusov, A.V. Panfilov, Interfloor slabs in stone houses Construction materials, equipment and technologies of the XXI century 11-12 (238-239) 20-23 (2018).

8. K. Leonenko, V. Shalenny, Justification of Energy-Saving Technology of Prefabricated Monolithic Slabs of Limestone Blocks. In: Murgul V., Pasetti M. (eds) International Scientific Conference Energy Management of Municipal Facilities and Sustainable Energy Technologies EMMFT 2018. Advances in Intelligent Systems and Computing, 982 (2020). DOI: https: //doi.org/10.1007/978-3-030-19756-8_74. 
9. D. Khodzhaev, B. Normuminov, Y. Mustapakulov, A. Mottaeva, E3S Web of Conferences 11001045 (2019). doi.org/10.1051/e3sconf /201911001045

10. Bubble Deck Technology Uses Less Concrete by Filing The Slab With Beach Balls https: //www.treehugger.com/green-architecture/bubble-deck-technology-uses-lessconcrete-filing-slab-beach-balls.html.

11. Sameer Ali, Manoj Kumar, Analytical Study of Conventional Slab and Bubble Deck Slabunder Various Support and Loading Conditions Using Ansysworkbench 14.0 International Research Journal of Engineering and Technology 04 (05) 1467-1472 (2017).

12. G. Afanasyev, and Serafima Selviyan Replacement of floor structures in capital repair with the use of not extractable void formers E3S Web of Conferences 9706045 (2019). https://doi.org/10.1051/e3sconf/20199706045.

13. V.V. Pavlov, Structures of floor slabs of reconstructed buildings Bulletin of civil engineers 1 (72) 38-42 (2019).

14. D. Chunyuk, A. Selviyan, S. Selviyan, Performance evaluation of the effectiveness of the use of core drivers in the construction of base plates E3S Web of Conferences 97 06029 (2019). https://doi.org/10.1051/e3sconf/20199706029.

15. N. Savitsky, D. Zezyukov, Innovations in the calculation of flat precast-monolithic floor slab Theoretical Foundations of civil engineering, Warsaw, 2009.

16. E.L. Butskaya, D.M. Zezyukov, N.N. Makhinko, O.G. Zinkevich, Justification of the optimal type of void former in a monolithic flat slab Bulletin of the Pridneprovsk State Academy of Civil Engineering and Architecture 3 10-18 (2019).

17. V. T. Shalenny, O. L. Balakchina, A.A. Smirnov, Pat. No. 185868 U1, Russian Federation, MPK E04B5/02, MPK E04B1/98 (2006.01). Monolithic floor slab construction Application No. 2017 147103. - Appl. 12/29/2017; publ. 20.12.2018, Bul. No. 35 .

18. Floor installation method. http://www.velox.cz/ru/assembling-of-ceiling.

19. T.A. Bakhtina, N.V. Lyubomirsky, A.S. Bakhtin, Lightweight building materials of carbonate hardening based on sawdust and lime binder Construction and mantriggered safety 13 (65) 91-98 (2018).

20. V.T. Shalenny, S.F. Akimov, K.A. Leonenko, I.M. Dolgoshapko, V.D. Malakhov, Pat. No. 190006 U1, Russian Federation, SPK E04B 5/36 (2020.01), E04G11/40 (2020.01). Precast monolithic reinforced concrete floor slab Application No. 2019 141926. Appl. 13.12.2019; publ. 13.02.2020, Bul. No. 5.-5s.

21. Seyran Akimov, Vasiliy Shalenny, Kirill Leonenko and Vladimir Malahov, $A$ resource-efficient development of VELOX-technologies during erection and reconstruction of prefabricated monolithic floor slabs. FORM-2020 IOP Conf. Series: Materials Science and Engineering 869072043 (2020). doi:10.1088/1757899X/869/7/072043. 